\begin{tabular}{|c|c|}
\hline & Asian Social Work Journal (ASWJ) \\
\hline $\begin{array}{c}\text { ASIAN SOCIAL WORK } \\
\text { SOURAL } \\
\text { (ASW) }\end{array}$ & Volume 4, Issue 1, February 2019 \\
& e-ISSN : $0128-1577$ \\
& Journal home page: \\
& www.msocialwork.com \\
\hline
\end{tabular}

\title{
Evaluation of Infection Prevention and Control (IPC) Program Implementation: A Case Study from One of the Private Hospital in Yogyakarta, Indonesia
}

\author{
Hanum Enggar Pradini ${ }^{1}$ \\ 1Universitas Muhammadiyah Yogyakarta, Indonesia \\ Corrrespondence: Hanum Enggar Pradini (hanumenggar@gmail.com)
}

\begin{abstract}
This research conducted at one of the private hospital was a special Type C Hospital in Yogyakarta that will carry out accreditation in 2018. By 2018, SNARS Edition I has applied as a new standard of accreditation. IPC is included in the hospital management standard group, so that the organizing system a good IPC can improve the quality of hospital services. The purpose of this study was to find out the management and implementation of the IPC at this hospital according to SNARS Edition I. This study used qualitative analysis methods with a case study design. The object in this study is the implementation of the IPC program which was assessed by survey and direct observation using the SNARS Edition I assessment instrument. Respondents in this study were 12 people. The results of the study showed that the IPC score was 39,8\%. The head of hospital had not implemented IPC managerial activities according to the guidelines. The IPC Team members have not been informed about their roles, the IPC program has not existed yet, and the surveillance record only noted without any further action, not even reported. Case of IDO tends to increase. Only two members of IPC Team $(18,18 \%)$ received official IPC training. Existing IPC regulations should be revised and completed especially related to risk management of infection, so it will have more impact on improving facilities and infrastructure. IPC program at this hospital has not yet reached the target based on SNARS Edition I.
\end{abstract}

Key words: accreditation, infection prevention and control, program implementation

\section{Introduction}

HAIs (Healthcare-Associated Infections) become the most vulnerable issues is not just a problem in hospitals but has also become a global problem. The incidence of HAIs in the world of events varies between $4-10 \%$. In the United States, the prevalence of HAIs in inpatients of 5-10\% and contributed to as many as 100,000 deaths per year. In the United Kingdom, estimated at $8-9 \%$ of patients contracted the infection is acquired from the health service. While in Indonesia the incidence of HAIs obtained only of $0-1 \%$ through passive surveillance (Griffiths, Peter, Renz, and Rafferty, 2008). This figure is quite small compared to the percentage incidence of HAIs in the developed countries, but the small percentage it can also describe the weak surveillance against the incidence of HAIs in health systems Indonesia. So that, HAIs become global challenges to the safety of the patients either in Indonesia or in the world and became the basis of the need for established a program to prevent and control infections in hospitals. In addition, implementing a habit of prevention of infections can increase the quality of service either directly or indirectly against the patient and the patient's family to become agents of change. 
In 2018, a new standard was adopted, namely Standar Nasional Akreditasi Rumah Sakit (SNARS) edition I, which was a refinement of KARS 2012. SNARS Edition I contains 16 chapters in which there are additions and revisions of the previous standard (Komisi Akreditasi Rumah Sakit bersama Keentrian Kesehatan Republik Indonesia (2017). Support to the implementation of the accreditation of the hospital then emphasized through Surat Edaran Kementrian Kesehatan Republik Indonesia No.: HK 02 02/I/. 3982/2017 about support implementation of Hospital Accreditation on 3rd points which states on January 1, 2019 all hospitals that cooperate with BPJS Health must be accredited in accordance with Permenkes 99/2015 about health services on Universal Health Coverage.

Currently, one of the Private Hospital in Yogyakarta is on process of the hospital accreditation process, which is expected in 2018 to have received an accreditation certificate for the first time. This became the basis of the considerations to do research on evaluation of IPC program implementation in one of the Private Hospital in Yogyakarta to know the readiness of hospital to face SNARS Edition I.

\section{Research Method}

This is descriptive research by using qualitative research methods. Specifically this research is a comparative descriptive study with a case study design. The location of the study was conducted in one of the Private Hospital in Yogyakarta. The time of this study was between June - September 2018. The subjects in this study were respondents who came from people who were considered competent in providing information regarding IPCs totaling 12 people. The respondents were divided into two groups, namely the IPC Team Members and Non- IPC Team Members. Data collection techniques in this study were carried out with three methods including: survey and direct observation, access to documentation, and interviews.

The data processing is done manually with a scoring process and coding interviews. Data analysis was done by finding of fact when the survey and observations regarding the implementation of the IPC program in one private hospital in Yogyakarta, seen from the system with a management approach and to compare in the elements in the assessment SNARS Edition I.

\section{Result and Discussion}

\section{Characteristics of Respondents}

Based on position classification, respondents from the IPC Team amounted to $58.33 \%$ of the total respondents. Characteristics of respondents are described in the following table:

Table 1. Characteristics of Respondents

\begin{tabular}{llcc}
\hline No. & Characteristics & Amount & Percentage \\
\hline 1. & Gender & 12 & \\
& Woman & 0 & $100 \%$ \\
& Man & & $0 \%$ \\
\hline $2 . \quad$ Clinical Profession & 2 & $16,67 \%$ \\
& Physician & 5 & $41,67 \%$ \\
& Nurse & 3 & $25 \%$ \\
& Midwife & 1 & $8,33 \%$ \\
& Nutritionist & 1 & $8,33 \%$ \\
\hline Others profession & & \\
\hline 3. & Educational Background & 0 & 0 \\
& Elementary & 0 & 0 \\
& Junior High School & 0 & 0 \\
& Senior High School & 9 & $75 \%$ \\
& Diploma & & \\
\hline
\end{tabular}




\begin{tabular}{llcc}
\hline No. & Characteristics & Amount & Percentage \\
\hline & Bachelor & 3 & $25 \%$
\end{tabular}

\begin{tabular}{|c|c|c|c|}
\hline \multirow[t]{7}{*}{4.} & Position & & \\
\hline & $I P C D$ & 1 & $8,33 \%$ \\
\hline & $I P C N$ & 1 & $8,33 \%$ \\
\hline & $I P C L N$ & 3 & $25 \%$ \\
\hline & Secretary & 1 & $8,33 \%$ \\
\hline & IPC Team Member & 1 & $8,33 \%$ \\
\hline & Non-IPC Team Member & 5 & $41,67 \%$ \\
\hline \multirow[t]{4}{*}{5.} & Length of Work & & \\
\hline & $<1$ year & 0 & $0 \%$ \\
\hline & $1-5$ years & 1 & $8,33 \%$ \\
\hline & $>5$ years & 11 & $91,57 \%$ \\
\hline \multirow[t]{4}{*}{6.} & Lenght of Membership & & \\
\hline & $<6$ months & 0 & 0 \\
\hline & 6 months -1 year & 1 & $14,29 \%$ \\
\hline & $>1$ year & 6 & $85,71 \%$ \\
\hline
\end{tabular}

\section{IPC Program Implementation}

Based on search results in accordance with the instruments of the SNARS Edition I, assessment score for IPC in one of the private hospitals in Yogyakarta was 39.8\%. The figure is still below the $80 \%$ so that it can be said did not pass the standard accreditation SNARS Edition I. There are some standards with a score of " 0 ":

1. IPC Standard 6.2: hospitals proactively perform risk assessment of infection that can occur and devise strategies to decrease the risk of infection.

2. IPC Standard 7: hospital carrying out the identification procedure and process a risky invasive infections of the orphanage as well as implement strategies to decrease the risk of infection.

3. IPC Standard 7.7: the hospital lowers the risk of infection in facilities related to the mechanical and technical control (mechanical and engineering controls).

4. IPC Standard 7.7.1: hospital lower the risk of infection at the time of demolition, construction, and renovation of the building.

5. IPC Standard 8.3: hospital to develop and implement a process to handle the air-borne infectious diseases outbreak.

Based on this, we can say that there are deficiencies in the standards related to risk management of infection. Risk management is the basis for preventing and reducing hazards arising from HAIs (National Health and Medical Research Council, 2010). National Patient Safety Goals Hospital based on the Joint International Commission that achieving patient safety is prevention of infection. One effort to prevent infection in hospitals is by using ICRA (Infection Control Risk Assessment, 2017).

\section{Leadership and Governance}

A new IPC Team was reformed in January 2017 which was previously a IPC Committee. The transition in the form of this Team was decided with consideration for streamlining the organization given the limited number of human resources. The current organizational structure is still not suitable when referring to the Infection Prevention and Control Guidelines in Health Service Facilities (Permenkes, 2017). With a capacity of beds below one hundred, then at the hospital enough to form a IPC Team under the direct director of the hospital (Peraturan Menteri Kesehatan Republik Indonesia, 
2017). The IPC team at the hospital consisted of the Chairperson of the IPC Team concurrently as an IPCD, one IPCN (Infection Prevention and Control Nurse) who are still not full time workers, other memberships consist of nurses, midwives, and nutritionist. This team membership is still not up to standard.

Based on the guidelines issued by the Ministry of Health of the Republic of Indonesia (Depkes RI), keep in mind that the success of the IPC in hospitals needs cross-professional involvement, physician, nurse, health analyst, pharmacist, nutritionist, K3L, IPSRS, sanitarian, and housekeeping. In the IPC Committee the members work together and support from managerial to implement the IPC program well. If the IPC Program is implemented well, the quality of hospital services will be guaranteed well (Departemen Kesehatan RI, 2008). Other deficiencies related to leadership and governance are regulations concerning the IPC Team which are not equipped with job descriptions along with appointment of members who have not yet been socialized so that in-depth interviews are still found by members those who do not understand their duties, especially IPCLN. Of all the respondents who participated as members of the IPC, only three people were able to answer questions completely while others did not know at all. According to Perdalin, the success factors of infection prevention and control programs in hospitals include: management support, organizational structure, roles and functions of IPCN (Infection Prevention and Control Nurse), IPC team authority (Prevention and Infection Control), available facilities, availability individual commitment to be aware, caring and responsible for preventing infection (Perdalin bekerjasama dengan Kementerian Kesehatan Republik Indonesia, 2015).

In depth interviews that have been conducted, the respondents from the IPC members who assessed the hospital leadership committed to implementing the IPC program showed that there were only two people (28.5\%) almost all of whom stated the lack of attention from the leadership of the IPC program at the hospital. A similar case is also shown on the associated priority direction of in-depth interview. According to Siagian, reflects the importance of a priority activity for the unit of work organization (Siagian, 2008). Permenkes RI No. 27/2017 states that the duties of the Hospital Leadership are to be responsible and have a high commitment to the management of prevention and control efforts, to conduct an evaluation of nosocomial infection prevention and control policies based on advice from the IPC team.

\section{Resource}

The IPC team has been formed and restructured twice due to the change of IPCD and sending Basic IPC training to the new IPCD. This can be said that there is support from the leadership and management so that IPC activities in the hospital can continue.

Only two members (18.18\%) Of all IPC Team members received official IPC education and training. This percentage still does not meet the Standar Pelayanan Minimal (SPM) based on Keputusan Menteri Kesehatan Nomor 129/Menkes/SK/II/2008 concerning Standar Pelayanan Minimal (SPM) which include trained IPC team members that is equal to $75 \%$ of all members, this become an indicator of assessment in accreditation. Whereas the last internal training related to Basic IPC for all employees was held in 2015 and based on training data at the hospital, until now there has been no Basic IPC training program for all employees.

In-depth interviews with two respondents from IPCD and IPCN said that staff in the IPC Team could not carry out tasks according to their respective job description. The obstacle found was that the average respondent who was a member of the IPC Team said that they had not yet received a decree on the appointment and description of the task from management.

The budget provided by the Hospital for the IPC Team was not mentioned and not well recorded, so the researchers only conducted in-depth interviews with respondents regarding budget support from management, stating that the special budgeting for the IPC Program had not been specifically classified. Some have been budgeted routinely such as the purchase of hand rubs, hand sanitizers, tissues, and gloves. Budgeting cannot cover the entire IPC program. On the other hand, the Rencana 
Kerja Anggaran (RKA) submitted from the IPC has not been made so that it becomes an burden in the submission and preparation of the IPC work program. Currently the hospital budget is prioritized for building repairs, inpatient rooms and the procurement of medical equipment. According to Annur, the process of drafting the RKA is the first step in implementing a work program that has been prepared, the current calculation can be used as a benchmark whether in the coming year the implementation of work programs can be carried out properly. ${ }^{9}$

\section{Goals of The IPC Program}

The results of interviews of researchers with respondents found that the implementation of the IPC in one of the Private Hospital in Yogyakarta began running since two years. Until now there has not been a separate IPC Team room, and full timer IPC member. Some facilities and infrastructure in accordance with IPC standards are under renovation, although there are still many facilities and infrastructure that have not met the standards set. In addition, the IPC program has not covered all aspects of the hospital, inadequate facilities and infrastructure, budgets that have not fulfilled all IPC programs and monitoring that have not been implemented optimally by the leadership. In line with the research conducted by Nelwan, Mandagi, dan Boky, It shows that in terms of quality, IPC program facilities and infrastructure are still adequate, but in terms of program adequacy, there are still obstacles. Delays in the provision of facilities after being traced through in-depth interviews are often caused by parties involved, both management mistakes that do not process requests on time, distributor providers who late provide due to long distances and the small number of requests, also late IPC committee errors propose requests to management (Annur, 2011).

At the time of the search found the documentation of IPC Program file at the hospital but still in draft form. IPC Program has functions so that officers know what are the things that must be achieved in a period of work of the organization. In another search, there was found an Infection Surveillance Guide. But in the guidelines it has not been found that hospitals in establishing programs use a risk-based approach. Infection prevention and control in hospitals is a program that needs to be supported by hospitals. In the interview with the IPCN stated that the IPC Team had difficulty making guidelines because of the lack of contributions from members to be invited to work to develop guidelines that were due to the dual role given to members of the IPC Team. For example, the head of the emergency room was concurrently as IPCLN, PIC, and was given the responsibility of being the coordinator of the Akses ke Rumah Sakit dan Kontinuitas Pelayanan (ARK) working group in accreditation.

The infection surveillance data in the hospital are made only by IPCN in the form of quarterly reports. The data obtained was only recorded in 2017. The details of the data obtained were UTI (Urinary Tract Infection) of $0 \%$, Phlebitis $0 \%$, and Infeksi Daerah Operasi (IDO) of $2.67 \%$. From these data the researcher graphed the trends of HAI's at the hospital.

Graphic 1. Analysis of Infection Surveillance Trends: One of the Private Hospital in Yogyakarta in 2017

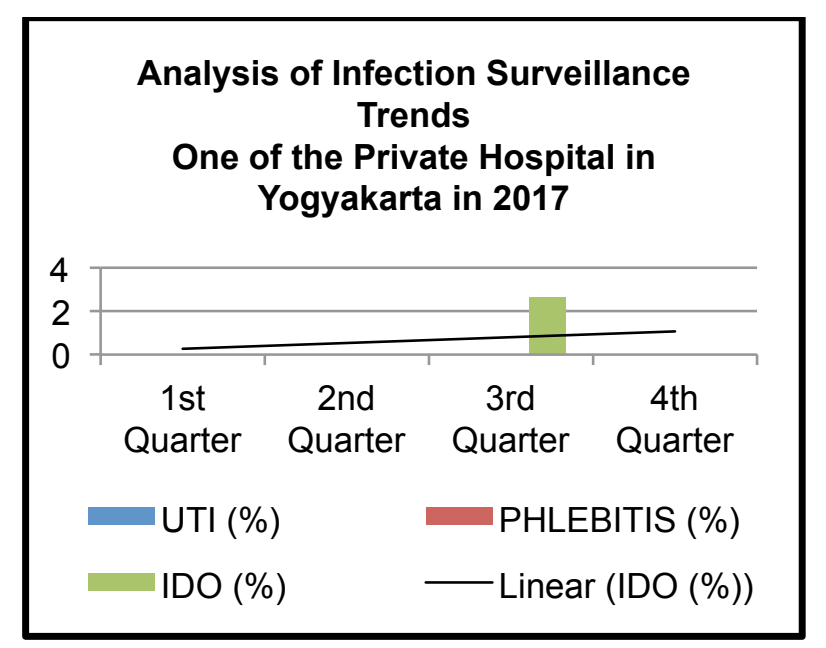


In the trendline graph shows an increasing trend in IDO cases. The IDO case appeared in the third quarter where in the previous period in 2017 there was no recorded IDO incident in one of the Private Hospitals. This shows a significant increase in the incidence of HAIs related to IDO so that it can be said that HAIs outbreaks occurred in that period. To be able to say an outbreak / epidemic, the number of cases does not have to be extraordinarily overwhelming in the absolute sense, but rather overwhelming in the relative sense, when compared with the usual incidence in the past, called endemic levels (Greenberg et al., 2005). Results of further searches related to seven IPC programs based on SNARS Edition I which were observed during the study were hand hygiene including the use of personal protective equipment (PPE) and Infection Surveillance.

\section{Hand Hygiene}

Based on direct observation in the inpatient room of health workers in the field, nurses who still do not have the awareness to wash their hands before and after contact with patients, do not use PPE such as gloves when carrying out nursing actions, and compliance with Standar Prosedur Operasional (SPO) is still low. Some of the reasons presented as a contributing factor are the limited availability of facilities and infrastructure in each hospital unit. It was seen in the maternity ward where there was no sink in the midwife's guard room, so the staff had to wash their hands in a bathroom far from the guard room or had to wash their hands in the emergency room as the closest building from the maternity ward in the hospital. In addition, another reason stated by the officers was that there was not enough time to wash hands because the time needed to carry out hand washing was 20-30 seconds while the officers did not necessarily memorize the six steps of hand washing. Hand washing is a mechanical process to release dirt and debris from the skin of the hands using soap and water (Kemenkes RI, 2011). On the other hand, the socialization provided by the IPC Team to health workers and all staff is routinely carried out, this is confirmed by evidence of attendance the meeting was summarized with the statement of respondents not members of the IPC who considered that socialization was often carried out during routine employee meetings on the $25^{\text {th }}$ of each month.

By documentation access, there is only one compliance monitoring data of officers in implementing hand washing SPO and PPE policies, where the results of the monitoring have not been analyzed by IPCN so that the evaluation stage of staff compliance with the use of PPE is not optimally evaluated. The factor of officers' disobedience to the use of PPE at the hospital was due to the absence of strict sanctions for officers who violated or did not implement the policy other than the lack of supervision by IPCLN nurses to control officers outside the official shift so that coordination of the nurse team leader in each shift.

\section{Surveillance of Risk Infection}

Infection surveillance data has been made in quarterly form but new reports have been made in draft form since 2017. The obstacles faced by IPCN nurses, namely in collecting data in the IPCN field are often not assisted by IPCLN, besides, IPCN sometimes have to be on shift because the amount of nurses in the hospital is still limited. Based on Permenkes RI, explained that monitoring is carried out by the IPC Committee / Team with a minimum frequency every month. In the IPC program monitoring and evaluation aims to measure the success of program implementation and compliance with implementation by officers and evaluation of the incidence of HAIs through an assessment of infection risk / Infection Control Risk Assessment (ICRA), audits, and other regular monitoring and evaluation conducted by the Committee or IPC Team.

\section{Medical Equipment and Devices}

Based on the results of the search, no regulations have been found governing drug dispensing carried out in the inpatient room, decontamination procedures described based on the type of device, and decontamination procedures made for units other than CSSD. During the observation it was still found that the implementation related to the supervision of expired tools and drugs still had not proceeded according to the procedure. Expired drugs are still found in one of the service units at the hospital. This indicates that the recording and reporting of expired drugs must be improved. 
The obstacle faced by the hospital was related to human resources and infrastructure in the linen laundry unit. When the search was obtained by several SPOs related to the management of linen laundry, in general the officers had carried out their duties according to SPO, especially in the use of PPE. There are still lacks of staff in the Linen Laundry unit, including: Management Experts, nurses, and Quality Control personnel. In terms of facilities and infrastructure, the linen laundry unit still does not meet the standards, including: linen separation room, decontamination room, chemical warehouse, and linen storage. So that the linen storage system in the hospital uses a decentralized system, where the finished linen is immediately distributed to the room. In the documentation search found findings regarding recording and reporting at the hospital. Every day the staffs have recorded but not in accordance with the linen management guidelines. Recording is done only in the form of documents on the amount of linen washed and distributed, the number of chemicals and the number of personal protective equipment used. Research conducted by Evania, Eti, and Dyah illustrates where there is still a need to increase the commitment of hospital management in planning linen by involving related units. Compliance with linen management guidelines (planning, procuring, identifying, distributing, recording and reporting) in accordance with the linen guidelines issued by the applicable ministry of health (Evania, Eti \& Dyah, 2014).

\section{Infectious Waste}

One of the private hospital has a IPC Guide to Management of Waste and Sharp Objects. At the time of searching there were still activities that did not meet the standards and were obstacles, including:

A. Regulatory Factors

Procedures related to the flow of B3 waste disposal are not in the SPO or the Guidelines.

B. Factors of Human Resources

1. The sanitarian officer is currently only one person and only comes every morning. So if there are a number of operations in a day, the nurse only identifies, separates infectious and non-infectious wastes then packs to be taken by the janitor. The results of research conducted by Raka, the prevalence of nosocomial infections in developing countries with resources is limited to more than $40 \%$ (Raka, 2010). According to Tietjen L, et. al. (1992) limited human resources in hospitals can be dealt with with discipline, work efficiency and high awareness of health services.

2. There are still hospital staffs who dispose of garbage not according to its type.

3. The clerk in disposing of the needle in the safety box is still not in accordance with the procedure so that inside it appears to be fully filled even though it is still below the line / $3 / 4$ sections.

4. Some janitors who enter the operating room, emergency room, VK, and inpatient unit only take the waste that has been packaged by the nurse without using a complete PPE.

5. Reporting and recording of waste has not been routinely carried out every month.

C. Factors of Facilities and Infrastructure

1. Lack of availability of garbage types according to type in the hospital toilet area so that it is still not right in sorting out landfills. According to Darmadi, as part of efforts to prevent and control infection in care rooms / wards, the presence of sanitation facilities is important, among others: bathroom and toilet WC, bathroom and toilet staff / family sufferers (gatekeepers), hand wash / sink, warehouse a place to store sanitary equipment, garbage containers / containers and waste, clean water (Darmadi, 2008).

2. Non-Infectious waste is not separated dry and wet.

3. The Radiology Unit still uses old technology that has not been CR (Computed Radiography) so that it is constrained in radiological liquid waste disposal.

\section{Food Service}

Observations in the field in terms of storing food ingredients are in accordance with the SPO and Nutrition Service Guidelines. It's just that the use of PPE such as a mask is still not routinely carried out by several officers. Based on Permenkes RI, masks are used to protect the face and oral mucous membranes from splashes of blood and body fluids from patients or the surface of dirty air 
environment and protect patients or the surface of the air environment from officers when coughing or sneezing. Household masks, used in the nutrition or kitchen section. The Nutrition Unit has a control checklist, which is a checklist for the implementation of food storage and nutritional products in which there are arrangements for sanitation, temperature, lighting, humidity, ventilation and security to reduce the risk of infection. The disadvantage of this checklist is that the routine unscheduled reporting and for evaluation and follow-up received little attention. The standard of building and kitchen facilities in the hospital is not yet in accordance with the standard. At present the nutrition unit only has one door access so that the nutrition service workflow cannot be done in the same direction. Workforce at the Hospital Nutrition Unit includes: Nutritionists, Administrative Staff, Cooks, and Waiters. In accordance with RI Minister of Health Regulation, states that in the event that there is no RD Nutrition Staff (Registered Dietitian), TRD nutrition staff (Technical Register Dietitian) and NR (Nutritionist registered) can carry out nutrition services independently or coordinate with other health workers in health service facilities where the nutritionist concerned is working (Peraturan Menteri Kesehatan Republik Indonesia, 2013).

\section{Construction Risk}

During the search, hospital regulations were found related to the Renovation or Construction Impact Risk Assessment, namely the Infection Control Risk Assessment Guide (ICRA), but the implementation in the Hospital was not yet running. The IPC ICRA activity in the hospital has not been programmed with a structured starting from risk identification. Risk Assessment of Renovation or Construction Impacts known as Infection Control Risk Assessment (ICRA) is a documented process carried out before starting maintenance, repair, demolition, construction and renovation activities to determine the risks and impacts on air quality by considering potential exposure to patients. ${ }^{5}$ According to The Joint Commission on Accreditation of Healthcare Organizations (JCAHO) in The Clinical Engineering Handbook (2007) requires hospitals to proactively carry out risk assessments as part of building demolition, construction and renovation. Infection control is one of the important issues discussed in the 2001 edition of the AIA guidelines. This guide now directs the ICRA process for each construction and renovation project. The ICRA process is defined as determining the potential risk of infection transmission in health facilities (Dyro, 2007).

\section{Transmission of Infection}

One of the Private Hospitals in Yogyakarta already has Guidelines for Patients Care with Infectious Diseases that are used as a reference for all staff involved in the service of patients with diseases that have a high risk of transmitting the disease, both in the isolation room and outside the isolation room. The isolation system used in the hospital is Cohort Nursing Isolation because it does not yet have a special isolation room. Patients who are exposed or infected, with the same micro-organisms can be treated in one room. The standard facilities used in the nursing cohort are similar to those expected in one isolation room, one of them is the ventilation system. Room doors must be closed at any time. Windows in a high room are allowed to open to provide environmental air cleaning. Fans should not be used. Priority in determining which patients enter the isolation room must be given to patients in the hospital who are suspected or confirmed include: diarrhea and vomiting, varicella, suspected cases of meningitis, suspected and confirmed cases of TB, diagnosed with multi-resistant organisms (MRSA). During observations in the field, the placement of patients is in accordance with the regulations, compliance with officers regarding hand hygiene has been carried out, but in terms of compliance with PPE officers in certain cases still cannot be carried out according to standards.

The implementation of the outbreak is still not in accordance with the standards, the hospital only has an outbreak guide. For its implementation regarding the outbreak team, the search for documents and interviews with IPCN is still not established due to constraints in human resources. According to Perdalin, the target of the program was achieved through surveillance activities managing important data and information, prevention of infections, especially the application of universal precautions and 
epidemic prevention by regulating, recommending policies and procedures, providing education and training to all personnel in hospitals, using rational antimicrobials. ${ }^{5}$

\section{Quality Improvement and Education Program/ Peningkatan Mutu dan Program Edukasi}

IPC activities have been integrated with the PMKP program at the hospital. The quality indicators of the IPC are the incidence of IDO Post cesarean section and the rate of use of antibiotics prophylactically before cesarean section. During the search, the measurement of quality indicators that were carried out was the incidence of IDO Post cesarean section but not until the data analysis stage and no evidence of reporting was found. Periodic meetings between the PMKP Committee and the IPC Team have also not been conducted. The meeting that had taken place only when setting the indicators of hospital quality.

\section{Conclusion}

The implementation of the Infection Prevention and Control program in one of the Private Hospital in Yogyakarta did not pass the minimum based score according to SNARS Edition I.

The head of one of the Private Hospital in Yogyakarta has not carried out IPC managerial activities in accordance with the guidelines set by the Permenkes RI No. 27/2017, which includes planning, supervision, guidance, monitoring, and evaluation of IPC implementation.

There found a leadership commitment to the IPC is but not optimal yet, because there have not been found RS documents related to the leadership priorities involving IPC in it.

The IPC Team's organizational structure is not yet in accordance with the arrangement stipulated by Permenkes RI No. 27/2017.

Appointment of Job Decree is only limited to IPCD and IPCN, so it is not socialized until IPCLN and other team members that cause ignorance of positions, responsibilities, and job descriptions in the IPC Team membership.

External basic IPC training has not been evenly distributed to all members of the IPC Team, while internal training carried out for all employees has not been held since the last three years.

The facilities provided by the hospital have not been adequate as seen from the unavailability of facilities and infrastructure in some units, especially in high infectious units, the incomplete supporting infrastructure to support the work of the IPC Team.

The IPC Team's work program in 2018 in one of the Private Hospital in Yogyakarta has not yet been agreed upon and submitted to the Director.

Implementation of recording and reporting of infection surveillance and integrated PMKP has not been implemented.

Trends in cases of IDO infection have experienced a significant increase in one of the Private Hospitals in Yogyakarta and in accordance with the definition of outbreak, so further investigation is needed.

\section{Acknowledgment}

The author expressed gratitude to Allah SWT, and appreciation to Mother, Father, Husband, and Son who has supported the author in completing this research. Thank you to dr. Ekorini Listiowati, MMR 
and Mrs. Elsye Maria Rosa, M.Kep as a mentor in this study who has made a significant contribution in the completion of this research.

\section{References}

Annur FAH. (2011). Proses Penyusunan Rencana Kerja dan Anggaran (RKA) di Kabupaten Kudus. Skripsi Diterbitkan Semarang: Universitas Diponegoro.

Darmadi. (2008). Infeksi Nosokomial ; Problematika dan Pengendaliannya. Salemba Medika, Jakarta.

Departemen Kesehatan RI. (2008). Pedoman Manajerial Pencegahan dan Pengendalian Infeksi di Rumah Sakit dan Fasilitas Pelayanan Kesehatan Lainnya.ed 2, Jakarta

Dyro, Joseph F. 2007. The Clinical Engineering Handbook, The Biomedical Engineering Series.

Evania, Eti, dan Dyah. (2014). Analisis Manajemen Linen di Instalasi Laundry Rumah Sakit Kasih Ibu Surakarta. Universitas Dian Nuswantoro.

Greenberg RS, Daniels SR, Flanders WD, Eley JW, Boring JR (2005). Medical epidemiology. New York: Lange Medical Books/ McGraw-Hill.

Griffiths, Peter., Renz Anna., Rafferty Anne Marie., (2008). The Impact of Organization and Management Factors on Infection Control in Hospitals: a Scoping Review. London: King's College London, University of London.

Joint Commission International. (2017). Hospital National Patient Safety Goals. The Joint Commission International Acreditation Hospital.

Kementrian Kesehatan Republik Indonesia.(2011). Standar Akreditasi Rumah Sakit.Jakarta : Kementerian Kesehatan R.I

Komisi Akreditasi Rumah Sakit bersama Keentrian Kesehatan Republik Indonesia. (2017). Standar Nasional Akreditasi Rumah Sakit Edisi I, Cetakan ke dua.

National Health and Medical Research Council.(2010). Australian Guidelines for the Prevention and Control of Infection in Health care, Healthcare Associated Infection Risk Management And Patient Safety Standards : Categorised guidance on recommended practice and legal and professional standards in Infection Control. Australian Goverment. NHMRC-ICG Project Team, Canberra.

Nelwan. R M., Mandagi, CKF., Boky Harvani 2017. Analisis Pelaksanaan Program Pencegahan dan Pengendalian Infeksi di Rsup Ratatotok Buyat Tahun 2017. Jurnal. Menado: Fakultas Kesehatan Masyarakat Universitas Samratulangi.

Peraturan Menteri Kesehatan Republik Indonesia Nomor 26 Tahun 2013 Tentang Penyelenggaraan Pekerjaan dan Praktik Tenaga Gizi.

Peraturan Menteri Kesehatan Republik Indonesia Nomor 27 Tahun 2017 Tentang Pedoman Pencegahan dan Pengendalian Infeksi di Fasilitas Pelayanan Kesehatan.

Perdalin bekerjasama dengan Kementerian Kesehatan Republik Indonesia.(2015). Pedoman Pelatihan Pencegahan dan Pengendalian Infeksi, Bapelkes, Medan.

Raka Lul (2010). Prevention and Control of Hospital-Related Infections in Low and Middle Income Countrie. University of Prishtina and National Institute of Public Health of Kosova.

Siagian, Sondang., P.(2008). Manajemen Sumber Daya Manusia (Edisi Pertama). Jakarta: Binapura Aksara.

Tietjen, et al. (1992). Processing instruments, gloves and other items, in Infection Prevention Guidelines for Family Planning Programs. EMS Inc. Durant 